\title{
Religious involvement over the life course: problems of measurement and classification
}

\author{
David Voas \\ voas@essex.ac.uk
}

Institute for Social and Economic Research, University of Essex

(Received June 2014 Revised February 2015)

http://dx.doi.org/10.14301/Ilcs.v6i2.311

\begin{abstract}
Longitudinal studies have the potential to enhance our understanding of stability and change in religious identity, practice and belief. Good individual-level data would help in developing and testing theories concerning the causes and consequences of religious involvement. Past research has shown, however, that even subtle differences in wording or context can substantially affect responses to questions on religion. The 1970 British Cohort Study offers an important opportunity to test the consistency of self-reported religion and religiosity. In addition, the 2012 sweep asked questions on belief in God and life after death as well as religious affiliation and practice, allowing us to explore the complexity of religious adherence. A close examination of the multiple waves of the BCS70 reveals a large amount of uncertainty in measurement, making it hard to detect whatever genuine change might have occurred. There are indications of considerable unreliability in reported past and present affiliation. It is also difficult to be confident about changes in religious commitment, though a substantial proportion of teenagers who reported that religion was an important part of their lives became relatively unreligious adults. The data on religious belief make it apparent that while some people seem wholly non-religious and a smaller number are actively (and consistently) religious, the majority fall into intermediate categories defined by nominal allegiance, unorthodox belief, or belief in the absence of affiliation or practice. It is clear that multiple survey items covering identity, practice and belief are needed to obtain a reliable picture of religious commitment.
\end{abstract}

Keywords: religion, religiosity, generations, cohorts, affiliation, identity, belief

\section{Why religion matters in life course research}

The founders of the modern discipline of sociology were deeply interested in the relationship between modernization and religion; both Weber and Durkheim wrote extensively on the topic. Social scientists continue to try to explain the relative prevalence of religious involvement in different times and places. Researchers study continuity and change, religious growth and decline, the connection between believing and belonging, non-traditional spirituality, the influence of age, gender and socio-economic characteristics, intergenerational transmission, and much else besides
(Beckford \& Demerath, 2007; Clarke, 2009; Fenn, 2000; Turner, 2010). Panel data, and particularly birth cohort studies, can provide invaluable clues to whether and why individuals are susceptible to shifts in religious identity, practice and belief over the life course.

A lively debate over the secularization thesis (asserting that modernization of a society erodes the power, prestige and popularity of religion) has continued for decades (Bruce, 2011). Although the inverse relationship between socio-economic development and aggregate participation in religion is clear, opponents of the thesis point to the United States and the persistent religiosity of societies that are now modernizing as counter-examples (Stark \& 
Finke, 2000). While the debate is frequently depicted in black and white, much of the recent research uses various shades of grey. It is commonly conceded that traditional religious organizations and orthodoxies are struggling, but many scholars claim that religion is being transformed rather than eroded. Belief and practice, in their view, are individualized, possibly privatized, but still with us (Heelas \& Woodhead, 2005). For secularization theorists, the issue is whether these new, less formal belief systems have the personal and social significance that characterized institutional religion.

A life course perspective is especially helpful in investigating the mechanisms of secularization. During childhood, religious identity, practice and belief are shaped by parents. How much effort parents invest in the religious socialization of their children is strongly associated with the importance they themselves attach to religion (Bengtson, 2013). As children emerge into adulthood, they may diverge from the family path; in the Western world, the motor of declining affiliation and attendance has been a drift away from religion at this point (Voas \& Crockett, 2005). Within any given generation, the average level of religiosity appears to be fairly stable over the life course; contrary to common belief, there is little evidence that people become markedly more religious with age (Crockett \& Voas, 2006; Dillon \& Wink, 2007). Exceptions are most likely to occur as a result of family formation, when people use their own upbringing as a model for how children should be raised (Stolzenberg, Blair-Loy, \& Waite, 1995).

Research on the causes of religious change is not the only reason to be interested in longitudinal data. Social scientists are more often concerned with the impact of religion on other aspects of life. In these studies religion is treated as an explanatory variable. Religion can affect health, drug and alcohol use, crime and deviance, fertility, mortality, marital stability, social and political attitudes, morality and altruism, tolerance, voting, civic participation, trust and social capital, education, economic activity, happiness and any number of other areas (Voas, 2007a). By far the largest literature is in health, where there are journals specifically dedicated to work in this field and thousands of articles have been published (Koenig, King \& Carson, 2012). The evidence suggests that the positive effects of religion (e.g. on lifestyle, emotional stability and in social support) are stronger than the negative ones (anxiety, fatalism, etc.), but the balance will depend on the particular case.

It is hard to deny the importance of religion in sustaining collective identities or motivating action, including conflict and even violence. For these and other reasons religion enters into public policy debates. A question on religion was included on the census of population in Great Britain for the first time in 2001, and similar questions have subsequently appeared on major national enquiries such as the Labour Force Survey. It needs to be established, though, whether these questions yield reliable data.

While understanding change over the life course would make an important contribution in all of these areas, we need first to be sure that any apparent changes are real. This study aims to test the reliability of responses on religious involvement. Measurement problems abound: it is not always clear what it means to have a religion or to be religious. There are multiple indicators of religiosity, and responses show high sensitivity to question wording and context.

The 1970 British Cohort Study offers an important opportunity to test the consistency of responses to questions on religion for a single cohort over three decades. The latest sweep (in 2012) asked questions on belief in God and life after death as well as religious affiliation and practice. A close examination of multiple sweeps of the BCS70 underlines the difficulties and limitations of using survey responses on religion (Sullivan, Voas, \& Brown, 2012). In what follows I look again at the (un)reliability of the traditional questions and consider how far new questions on religious belief improve our understanding of the cohort members.

\section{Religion versus religiosity}

It is common to think of religion itself - Catholic, Anglican, Hindu, Buddhist - as the key variable in this domain. For some people, however, affiliation is purely nominal; others will have a serious personal commitment, seeing faith as important in their lives. Notional affiliation may matter less than degree of religious commitment, or 'religiosity'. (This term is used non-pejoratively to mean the quality of being religious, not the display of excessive or affected piety.) Religiosity is bound up with attitudes, behaviour and values, while religion 
per se is arguably more like ethnicity or cultural heritage, something that may or may not be salient.

These two concepts lead to quite separate questions. On the one hand there is the issue of the social significance of being Methodist, Mormon or Muslim, relative to having some other affiliation, or none; on the other, the issue is how far degree of religiosity matters. Change over time may be a matter either of growth or decline in particular denominations or in the commitment shown by those involved. The challenge for social scientists has been to find variables that capture the different dimensions of religious involvement. From a life course perspective, an additional consideration is that affiliation and practice may mean different things at different points, as religion is variously associated with familial culture or autonomous choice.

Table 1 lists the key questions on religion that have been used in the BCS70. Religion of upbringing and current religious identity concern affiliation.
Although self-identification with a religion does not necessarily entail commitment, the growth in the number of those who say that they have no religion has ironically turned the simple willingness to accept a denominational label into an indicator of religiosity. The questions shown in the lower part of the table - on religious practice and belief relate more straightforwardly to religiosity.

Attendance at services is a standard measure of commitment, though it is far from perfect. Some people attend for personal, family or social reasons in the absence of faith or even affiliation. Some groups (e.g. Catholics) attach more importance to it than other denominations. In some religions (e.g. Islam and Orthodox Judaism) the obligation falls on men rather than women. Overstatement of attendance is common (Hadaway, Marler, \& Chaves, 1993), to a degree that may vary according to subjective perceptions of the social desirability of religious activity.

\title{
Table 1. Questions on religion in BCS70 by topic and survey year
}

\author{
Upbringing / heritage \\ 1986 What religion were you born into? + tick boxes \\ 2004 Were you raised according to any particular religion? + showcard if 'yes' * \\ 2012 Were you raised according to any particular religion? + tick boxes \\ Identity / affiliation \\ 1996 Do you regard yourself as belonging to any particular religion? + write-in \\ 2000 What is your religion, if any? + showcard* \\ 2012 Do you now see yourself as belonging to any particular religion? + tick boxes \\ Self-perception / behaviour \\ 1986 Is religion an important part of your life? [three options + NA + DK] \\ 2004 Do you actively practise any religion now? [If 'yes'] How often, if ever, do you \\ $2012 \quad$ How often, if ever, do you attend any kind of religious service or meeting?
}

Belief

2012 Which of these statements comes closest to expressing what you believe about God? [six options]

Do you believe in life after death? [four options]

* Asked in a face-to-face interview; questions not so marked appeared on self-completion forms. 


\section{Religious change in Great Britain}

Religious affiliation in Great Britain has declined in recent decades. As shown in Figure 1, the changes arise entirely from differences between rather than within generations. The lines for each birth cohort are essentially horizontal: there is remarkable stability over the adult life course in religious identification, at least in aggregate. By contrast, affiliation drops from one cohort to the next for years of birth going back to the beginning of the 20th century. Note in particular the line for people born 1965-74, which can be used as a proxy for the 1970 birth cohort.

Figure 1. Belongs to a religion (\%) by decade of birth and survey year (BSA 1983-2011)

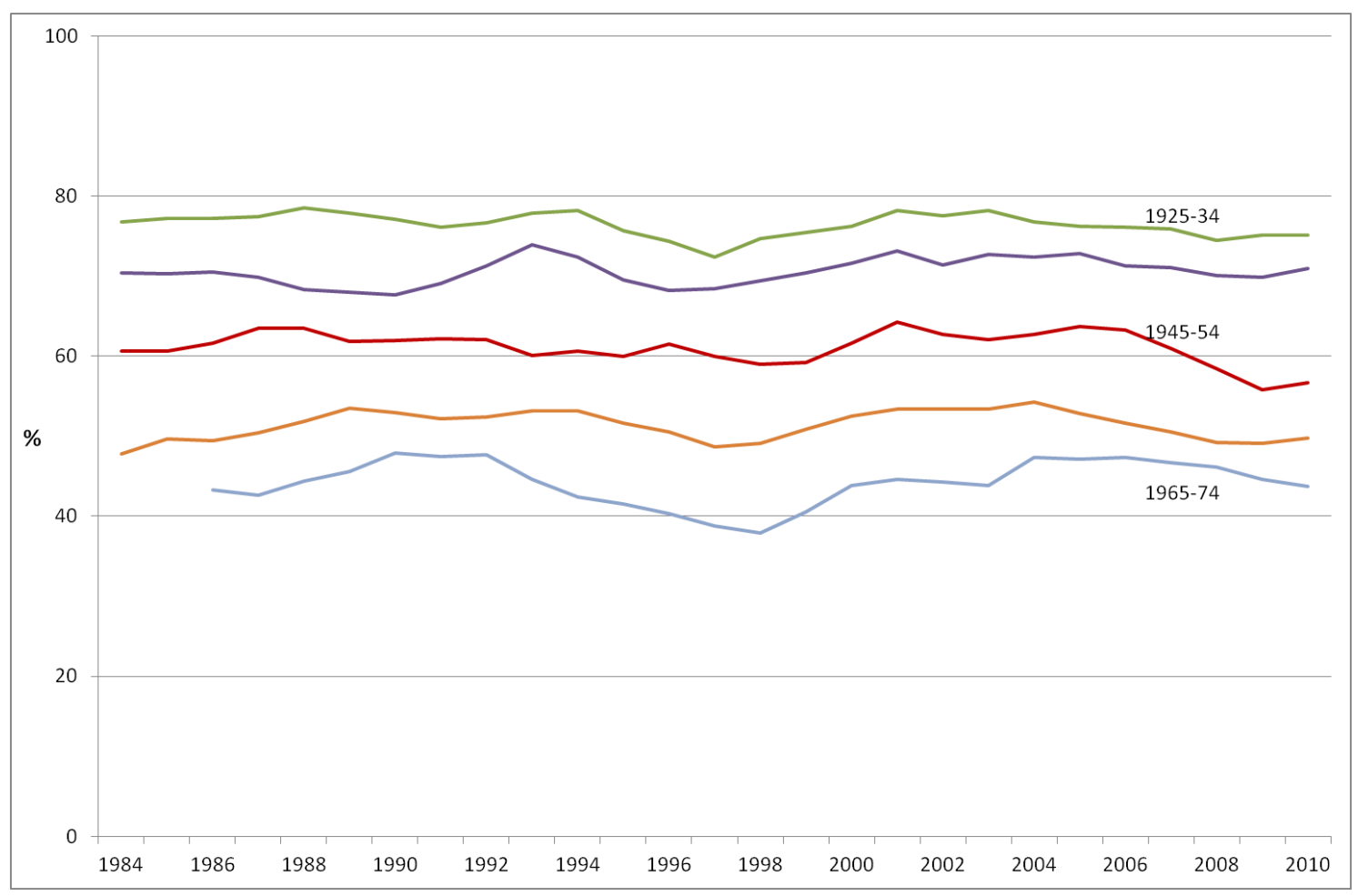

Source: British Social Attitudes survey, 1983-2011. Three-year moving average. The count in each individual cohort and survey year ranges from 124 to 851.

The same is true for attendance at services. There are substantial differences between the oldest generations (among whom close to $30 \%$ claim to attend at least monthly) and the youngest (among whom the figure is around 9\%). Secularization is being driven by generational replacement.

These repeated cross-sectional surveys suggest that religious practice as well as affiliation is fairly stable over the adult life course. No cohort seems to have either higher or lower attendance at the beginning than at the end of the three decades covered by the British Social Attitudes surveys. People do not seem to become much more religiously active with age, but nor have they become less active over time.
The aggregate stability may disguise a good deal of individual-level volatility, however. A comparison of waves 1 and 9 (1991 and 1999) of the British Household Panel Survey shows that the frequency distribution of religious affiliation is utterly static, from which it is tempting to conclude that religious identity is a stable attribute. Closer examination at the individual rather than the aggregate level reveals that a remarkable $27 \%$ of respondents interviewed in both surveys supplied different religious labels for themselves at the two dates (Voas, 2007b). No doubt some of those panel members really did change allegiance (between denominations or between affiliation and no religion), but it is likely that many are simply uncertain or ambivalent. The line between having 
an affiliation and none can be rather fuzzy, and people in this 'liminal' area (sometimes stating a religious identity and sometimes not) may have distinct characteristics (Lim, MacGregor, \& Putnam, 2010).

The key issue in looking at individual change is whether we are seeing real shifts in religious identity or religiosity, measurement error, or a kind of indifference that translates into a liminal state between having and not having a religion (Voas, 2009).

\section{Do we know who was raised in a religion?}

Cohort surveys make it possible, at least in principle, to see whether someone is changing and in what direction. The BCS70 has gone back to the same people year after year, decade after decade, to find out what is new and what has stayed the same. There are also ways of creating a time series other than through contemporaneous data collection, and the cohort study asks respondents to reconstruct their family, education or work histories. Such retrospective data are also useful with religion; at the simplest level respondents can be asked whether they were raised in one. People could also be asked about their childhood attendance at religious services, the religious affiliation or practice of their parents at that time, and so on, though such data are not available in the BCS70.

The overwhelming majority (93\%) of cohort members (CMs) responding at age 16 reported that they had been 'born into' a religion. More than two thirds (69\%) of those naming a religion specified the Church of England, which seems rather high. We know, for example, that exactly half of people born in England in 1970 had Anglican christenings (Voas, 2003). Not everyone 'born into' the religion would necessarily have been baptised, but then the BCS70 also includes people from Scotland and Wales, where the Anglican proportion is considerably lower.

The considerable majority of $\mathrm{CMs}$ who claimed in 1986 to have been born into a religion did not identify with it ten years later. In 1996, only $39 \%$ of CMs responding to a postal survey saw themselves as belonging to any particular religion. The importance of religion at age 16 is a reasonably good predictor of who did or did not retain an affiliation, as shown in Table 2.

Table 2. Belonging to a religion at age 26 by importance of religion at age 16 (\%)

\begin{tabular}{lccr} 
Religion important, & \multicolumn{3}{c}{ Belongs to a religion, age 26 } \\
age 16 & Yes & No & N \\
\hline Yes, very important & 86 & 14 & 353 \\
Yes, quite important & 68 & 32 & 924 \\
Don't know & 41 & 59 & 238 \\
No, not important & 31 & 69 & 2,313 \\
Have no religion & 11 & 89 & 395 \\
& & & \\
& 1,778 & 2,445 & 4,223
\end{tabular}

The sweeps at ages 34 and 42 included essentially identical questions on religious upbringing. The responses were very different: at age 34 only $55 \%$ said that they had been raised according to a religion, while at age 42 the figure was $67 \%$. In 2004 the religion questions were asked in a face-to-face interview, whereas in 2012 they appeared on the self-completion form. The earlier version was a two-stage question (first the yes/no filter, then a list of religious groups), while the later question was unitary. Still, the contrast in responses seems astonishing, given that the surveys were only eight years apart and the respondents were in mid-life. The findings shown in Table 3 may shake our confidence in the possibility of studying religion using retrospective data. 
Table 3. 'Thinking first of your childhood, were you raised according to any particular religion?' Responses in 2004 and 2012

\begin{tabular}{ccccrr} 
& \multicolumn{2}{c}{ 2012 response (\%) } & & \\
2004 response & Yes & No & Total & $\boldsymbol{N}$ \\
\hline Yes & 90 & 10 & 100 & 3,888 \\
No & 40 & 60 & 100 & 3,070 \\
& & & & 6,958
\end{tabular}

Respondents who had a religion in 2012

$\begin{array}{rrrrr}\text { Yes } & 97 & 3 & 100 & 2,585 \\ \text { No } & 76 & 24 & 100 & 929 \\ & & & & 3,514\end{array}$

Respondents who had no religion in 2012

$\begin{array}{lllll}\text { Yes } & 76 & 24 & 100 & 1,263 \\ \text { No } & 25 & 75 & 100 & 2,121 \\ & & & & 3,384\end{array}$

Overall about a quarter of people flip-flop (as predicted by the 'law' that "a quarter of responses to any question on religion are unreliable", Voas, 2007b: 149), and as seen in the lower segments of Table 3 the ones most prone to it (accounting for $43 \%$ of all switchers) are those with an affiliation who said in the earlier period that they were not raised in a religion. These respondents are evidently unsure about how to describe their childhood experience, and this lack of clarity may simply suggest that their religious upbringing was weak. An alternative hypothesis is that people tend to reconstruct their histories to make them consistent with their present status.

As mentioned above, $93 \%$ of responding $\mathrm{CMs}$ in 1986 said that they had been born into a religion. In 2012, two thirds (67\%) claimed to have been raised according to a religion. As one might expect, relatively few people (20\%) who said at age 16 that they were not born into a religion claimed at age 42 to have been raised in one. The main contrast is the shift from 'born into' to 'not raised according to'. A quarter of the whole sample responding at both dates fall into this group.

Of respondents who said that they were born into the Church of England (C of E) at age 16, slightly fewer than half said that they were raised $C$ of $E$ at age 42. Just short of a third said that they were not raised in a religion, and most of the remainder gave 'Christian' as their religion of upbringing.

The social class of parents at birth of the $\mathrm{CM}$ is closely related to upbringing reported at age 42: $62 \%$ in classes V and IV were raised in a religion, versus $76 \%$ of professionals (I). The same does not apply to 'religion born into' reported at age 16, where it is $92 \%$ for classes IV and V, 94\% for III, 92\% for II, and $90 \%$ for I. A similar U-shaped pattern is seen for the importance of religion.

There is a large gender gap in current affiliation (2012): $57 \%$ vs $43 \%$ for women and men respectively. Although one might suppose that there would be no gender difference in the proportion with a religious upbringing, there is a gap here, too: $69 \%$ vs $65 \%$. It seems likely that this difference is largely the result of respondents ironing out the extent of change, but a portion might be genuine (if boys and girls are socialized differently with respect to religion).

For people brought up with a religion, most were raised as Anglican, Catholic or Christian (no denomination). Among men, about $60 \%$ of Anglicans and Catholics and $54 \%$ of the Christians retain the identity. Among women, the figures are $77 \%$ and $69 \%$. Thus women are somewhat more likely than men to report having had a religious upbringing, and among those who do, women are much more likely than men to continue to identify with a religion. 
Men are disproportionately likely to report being raised in no religion or as 'Christian', while being less likely than women to report being raised as Anglican or Catholic. The difference is 2 percentage points for both Catholics and Anglicans, though as the base is about $10 \%$ and $30 \%$ respectively, men seem particularly disinclined to report a Catholic upbringing.

\section{How reliable are statements about religious identity?}

In 1996 and 2012 the wording of the question about religion was that used in the British Social Attitudes survey, whereas in 2000 it corresponded to the question that had been adopted for the 2001 census. A considerable amount of attention has been given to the differences that result (Voas \& Bruce, 2004). The contrast is especially stark in the BCS70. At age 26 , only $39 \%$ of responding CMs said that they regarded themselves as belonging to a religion. Four years later, at age 30 , nearly twice as many $(74 \%)$ chose a religious group when asked "what is your religion, if any?". Among people responding to both surveys, the considerable majority (61\%) of those who answered negatively in 1996 did name a religion in 2000.

The difficulty of framing an entirely neutral question about religious affiliation is evident (Voas, 2007b; Voas \& Bruce, 2004). "What is your religion?" seems to imply that the respondent should have one (though the addition of "if any" clearly helps). Conversely, the term 'belonging' might be understood as requiring active participation rather than passive self-identification. The 2012 question ("Do you see yourself as belonging to any particular religion?") tries to counter-balance the apparent commitment of 'belonging' with the subjectivity of 'see yourself', but the wording could be read as sceptical and hence off-putting: "Do you really see yourself as being part of some religious group [despite your lack of involvement]?" How respondents interpret the question is far from clear.

A further puzzle is the contrast between responses at ages 26 and 42 (Table 4). Although the questions appear to be the same, identification with a religion rises from $40 \%$ in 1996 to $52 \%$ in 2012 . This shift might suggest that cohort members had genuinely become more religious, but evidence from elsewhere (e.g. the British Social Attitudes survey, as shown in Figure 1) make it unlikely. Framing effects might be a factor: in 2012 respondents are first asked whether they were raised according to any particular religion, which could incline them to give a consistent answer to the follow-up on current belonging. The most probable explanation concerns a subtle difference in the way the responses were recorded. Both sweeps used self-completion forms, but in the 1996 the question was no/yes, where the respondent was asked to write in which religion if 'yes' was ticked, while in 2012 there was a list of tick boxes with 'no religion' as simply one of the options. Answering 'yes' in 1996 thus involved more work both in deciding what to call the religion and in writing the name on the form - than in 2012. Such 'satisficing' behaviour by survey respondents has been widely observed, even to the extent of omitting children ( $\mathrm{Ni}$ Bhrolchain, Beaujouan, \& Murphy, 2011).

\section{Table 4. "Do you regard yourself as belonging to any particular religion?" (1996) “Do you now see yourself as belonging to any particular religion?" (2012) Responses in 1996 and 2012}

\begin{tabular}{ccccrr} 
& \multicolumn{2}{c}{ 2012 response (\%) } & & \\
1996 response & Yes & No & Total & $\boldsymbol{N}$ \\
\hline Yes & 80 & 20 & 100 & 2,371 \\
No & 33 & 67 & 100 & 3,567 \\
& & & & 5,938
\end{tabular}




\section{How stable is religiosity?}

In view of the unreliability of religious affiliation, not to mention the uncertainty over its personal significance, it might seem preferable to focus on religiosity. One approach was that used in 1986, when the teenage CMs were asked about the importance of religion in their lives. Another is to enquire about religious activity. An intermediate concept is that of 'practising a religion', as used in 2004 (Tables 5 \& 6). Most (81\%) respondents who said that they practised religion attended services at least monthly.

One problem with this approach is that a relatively small minority of the British population is now 'practising': in 2004 , only $14 \%$ claimed to be, and only $10 \%$ said in 2012 that they attend services at least monthly (though $25 \%$ do so occasionally). Another problem is that reported religious activity also varies over time. Of people who described themselves as practising in 2004 and who claimed to attend at least monthly, only a bare majority (54\%) were still doing so in 2012 . While there might be genuine change - for example if some of the attendance at the earlier period was motivated by school choice - there is also likely to be a good deal of churn as people move in and out of churchgoing, and the unreliability of responses will also contribute.

Table 5 . Whether practising a religion at age 34 by importance of religion at age 16

Whether practices any religion, age 34

Religion important,

\begin{tabular}{lrrr} 
age 16 & Yes & No & $\boldsymbol{N}$ \\
\hline Yes, very important & 55 & 45 & 357 \\
Yes, quite important & 28 & 72 & 936 \\
Don't know & 13 & 87 & 240 \\
No, not important & 8 & 92 & 2,418 \\
Have no religion & 3 & 97 & 377
\end{tabular}

4,328

Table 6. Attendance at services at age 42 by importance of religion at age 16

\begin{tabular}{lccr} 
Religion important, & Attends at least sometimes, age 42 \\
age 16 & Yes & No & N \\
\hline Yes, very important & 67 & 33 & 324 \\
Yes, quite important & 43 & 57 & 843 \\
Don't know & 24 & 76 & 217 \\
No, not important & 18 & 82 & 2,161 \\
Have no religion & 10 & 90 & 351
\end{tabular}




\section{Are beliefs consistently religious or unreligious?}

There is a general assumption among religiously educated people in Western countries that God and life after death are linked. Christianity teaches that souls exist because God exists, and they survive because there is a supreme being who has made it so, as an expression of both love and judgement (Astley, 2010). But what do people actually believe? How closely does folk religion or popular theology coincide with conventional or official doctrine?

Every level of theism (belief in God) can be found among BCS70 members, who in this respect are characteristic of Europeans generally. Likewise belief in life after death is highly varied (Table 7). But belief - or disbelief - in God and in life after death do not always go together. First, the strength of belief is often different. Even among people at the extremes on the theism scale, many people are far from confident about the afterlife. In the BCS70, only two thirds of those who say 'I know that God really exists and I have no doubts about it' think that there is definitely life after death. Only a bare majority of atheists think that there definitely is not. In the other four response categories on theism, only a small minority are definite one way or the other about life after death.

Secondly, the combinations often seem inconsistent by the standards of conventional religion. A quarter of agnostics believe in life after death. Among people who say that notwithstanding occasional doubts they believe in God, nearly a third do not. Even with the atheists and the undoubting theists, an appreciable proportion hold the 'opposite' view about life after death.

\section{Table 7. Belief in God and life after death at age 42 (\%)}

I don't believe in God.

I don't know whether there is a God and I don't believe there is any way to find out.

I don't believe in a personal God, but I do believe in a Higher Power of some kind.

I find myself believing in God some of the time, but not at others.

While I have doubts, I feel that I do believe in God.

I know God really exists and I have no doubts about it.

Believes in life after death

$\begin{array}{lr}\text { Yes, definitely } & 18 \\ \text { Yes, probably } & 30 \\ \text { No, probably not } & 35 \\ \text { No, definitely not } & 17 \\ \text { otal } & 100\end{array}$

$N=8,579$ for belief in God; $N=8,553$ for belief in life after death 
Figure 2. Belief in God and life after death, 2012

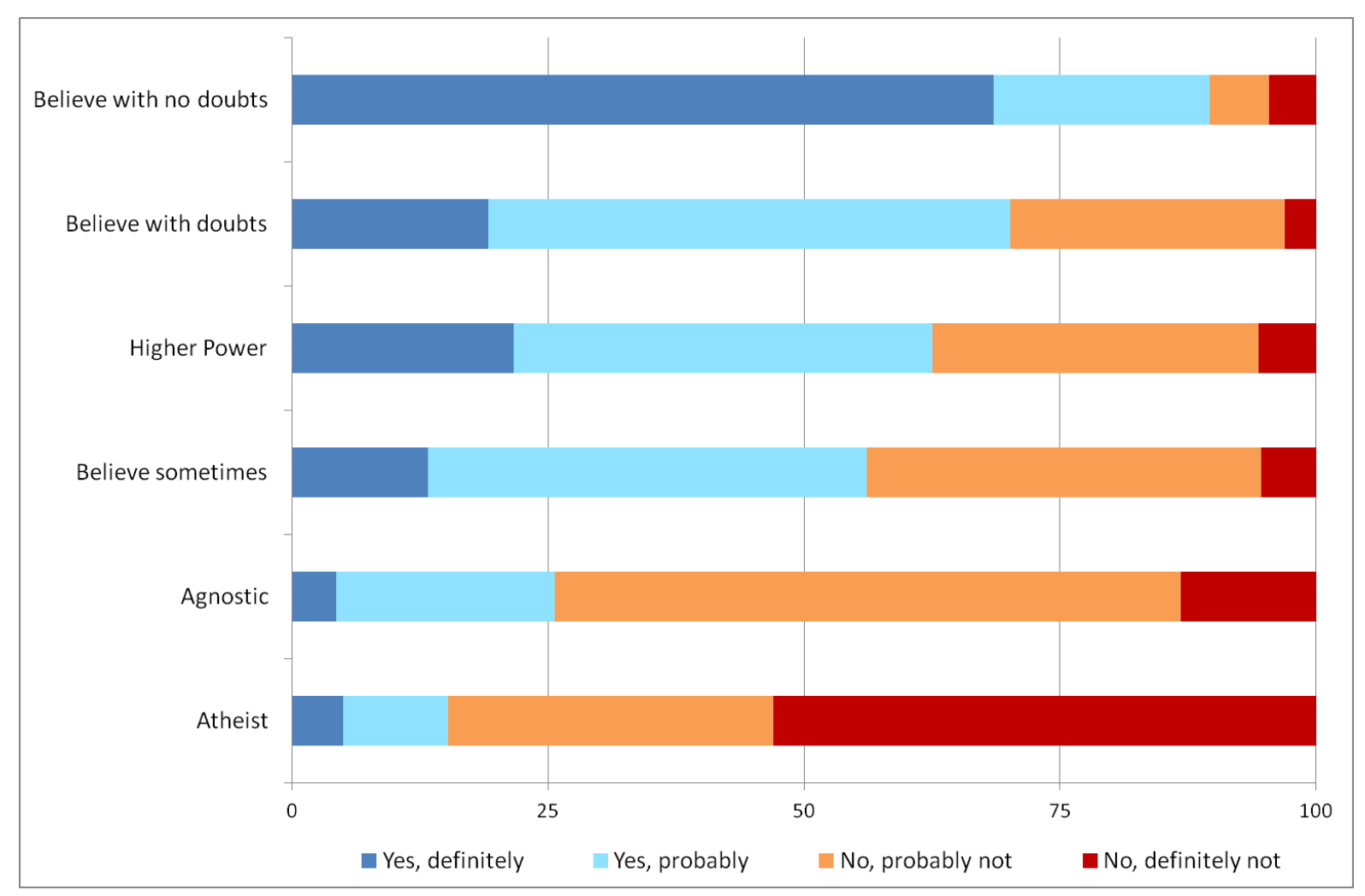

$N=8,479$

Figure 3. Belief in God and life after death by gender, 2012

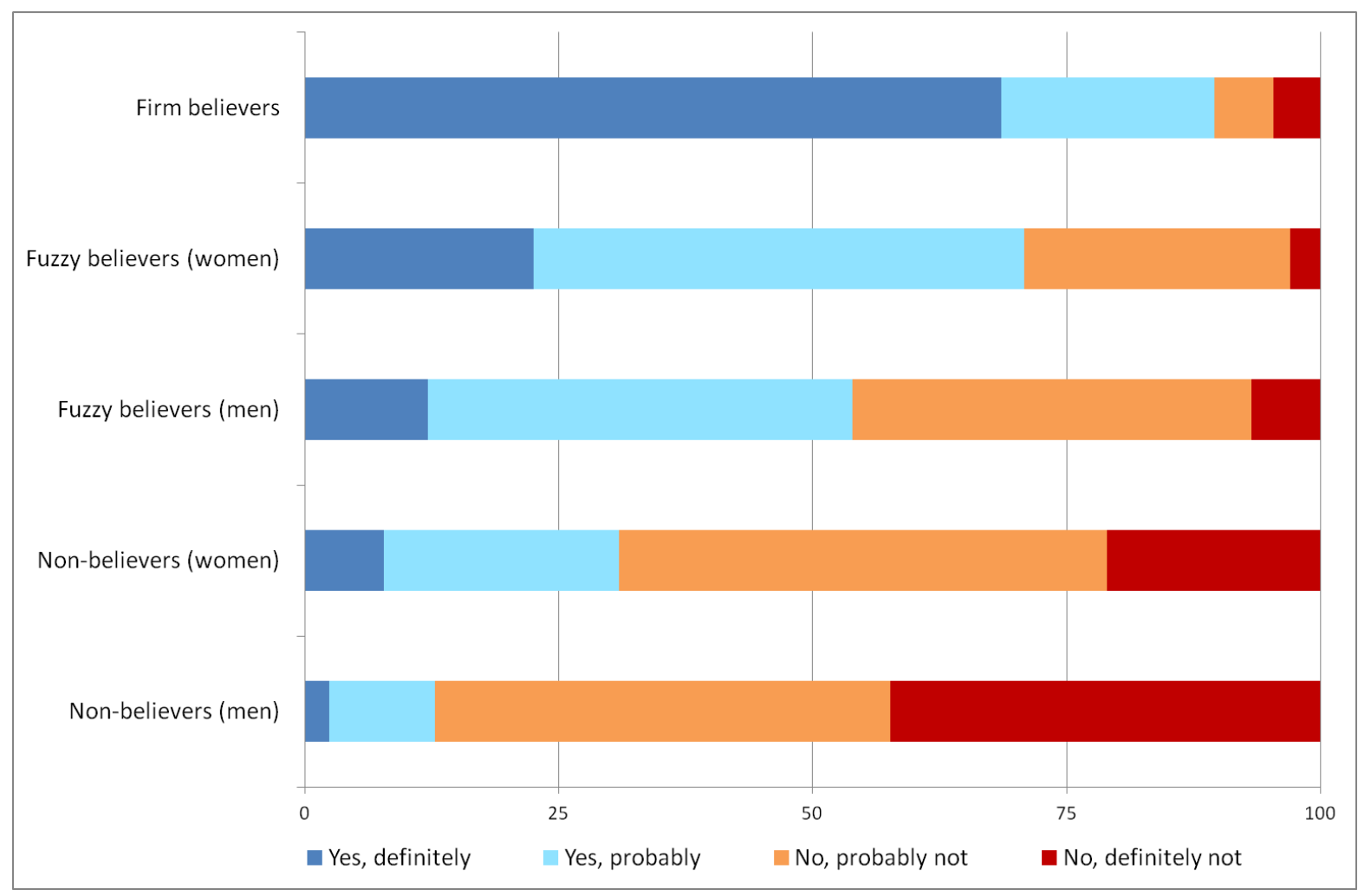

$N=8,479 \quad$ Notes. 'Non-believers' are atheists and agnostics; 'Fuzzy believers' believe sometimes, believe in a Higher Power, or believe with doubts; 'Firm believers' have no doubts. 
Religious upbringing has a strong influence on belief in God, but not nearly such a strong effect on belief in life after death. Of people raised with a religion (and recorded as such in both 2004 and 2012), 45\% believe in God (with or without doubts). Only $29 \%$ are atheists or agnostics. Of people without a religious upbringing, two thirds (66\%) are atheists or agnostics, and only $12 \%$ believe in God.

Life after death divides the cohort members down the middle, with just slightly fewer than half (48\%) believing. Only a bare majority $(54 \%)$ of even those raised in a religion believe in it, compared to $36 \%$ among those not raised in a religion.

Gender differences in religious belief are very substantial: $54 \%$ of men, but only $34 \%$ of women, are atheists or agnostics. The gap is even larger for belief in life after death: $60 \%$ of women but only $35 \%$ of men. Among believers, women are much more likely to be definite than men, and among non-believers, men are much more likely to be definite than women. Thus even controlling for belief in God, the gender gap in views about life after death is considerable (Figure 3 ).

\section{Does religious belief coincide with religious identity?}

Exactly half the respondents in the 2012 sweep report having a religion, and roughly half $(48 \%)$ believe in life after death. Two thirds of these groups overlap: $67 \%$ of those with no religion do not believe, $63 \%$ of those with a religion do believe; $66 \%$ of believers in life after death belong to a religion, while $64 \%$ of non-believers do not belong. Or to put it another way, $33 \%$ neither belong nor believe, $32 \%$ belong and believe, and the remaining $35 \%$ is split between the 'inconsistent' categories.

Table 8. Belief in God and life after death by religious identity at age 42 (\%)

\begin{tabular}{|c|c|c|c|c|c|c|c|c|c|}
\hline & $\begin{array}{l}\text { No } \\
\text { religion }\end{array}$ & $\begin{array}{l}\text { Main- } \\
\text { line }\end{array}$ & $\begin{array}{l}\text { Roman } \\
\text { Catholic }\end{array}$ & $\begin{array}{l}\text { Evan- } \\
\text { gelical }\end{array}$ & Buddist & Jewish & $\begin{array}{l}\text { Hindu } \\
+ \text { Sikh }\end{array}$ & Muslim & Othe \\
\hline I don't believe in God & 40 & 5 & 2 & 0 & 40 & 18 & 1 & 1 & 10 \\
\hline $\begin{array}{l}\text { I don't know whether } \\
\text { there is a God }\end{array}$ & 29 & 16 & 7 & 2 & 10 & 20 & 10 & 1 & 4 \\
\hline $\begin{array}{l}\text { Believe in a Higher Power } \\
\text { but not a personal God }\end{array}$ & 15 & 14 & 6 & 2 & 45 & 9 & 14 & 1 & 42 \\
\hline $\begin{array}{l}\text { I believe in God some of } \\
\text { the time but not at others }\end{array}$ & 8 & 17 & 14 & 2 & 5 & 25 & 12 & 2 & 7 \\
\hline $\begin{array}{l}\text { While I have doubts, I feel } \\
\text { that I do believe in God }\end{array}$ & 7 & 31 & 38 & 23 & 0 & 16 & 26 & 6 & 12 \\
\hline $\begin{array}{l}\text { I know God really exists } \\
\text { and have no doubts }\end{array}$ & 2 & 16 & 33 & 71 & 0 & 11 & 37 & 88 & 25 \\
\hline Total & 100 & 100 & 100 & 100 & 100 & 100 & 100 & 100 & 100 \\
\hline \multicolumn{10}{|l|}{ Believes in life after death } \\
\hline Yes, definitely & 10 & 21 & 35 & 68 & 40 & 21 & 29 & 73 & 54 \\
\hline Yes, probably & 23 & 38 & 36 & 17 & 25 & 26 & 47 & 12 & 26 \\
\hline No, probably not & 40 & 33 & 26 & 7 & 30 & 40 & 15 & 6 & 11 \\
\hline No, definitely not & 27 & 8 & 4 & 8 & 5 & 14 & 9 & 9 & 8 \\
\hline Total & 100 & 100 & 100 & 100 & 100 & 100 & 100 & 100 & 100 \\
\hline N & 4,210 & 3,145 & 603 & 133 & 20 & 44 & 86 & 82 & 130 \\
\hline
\end{tabular}

Notes. 'Mainline' includes Christian (no denomination), Anglican, Methodist, Presbyterian and URC. 'Evangelical' includes Baptists and other Christians. 
As one would expect, people who do not see themselves as belonging to a religion tend to be non-believers. That said, a third believe in life after death and close to the same number believe in God or a higher power, if only sometimes. The differences are small between people who identify with the various 'mainline' denominations (to adopt the American term), and hence those Christian groups have been collapsed in Table 8. Many of them express doubts about God and life after death. There is a higher level of belief among Roman Catholics and evangelical Protestants (defined here as Baptists and other Christians, though not all of the latter will in fact be evangelical). The numbers in the non-Christian categories are small, but the very high level of belief in both God and life after death among Muslims is noteworthy.

Belief in God can be dichotomized by contrasting atheists and agnostics with everyone else (including those who say that sometimes they believe and sometimes they don't). On that basis, $43 \%$ are nonbelievers. The overlap between belief in God and in life after death is far from complete: $39 \%$ believe in both, 35\% are consistent non-believers, and the remaining $26 \%$ are split (mostly theists who do not believe in an afterlife). Interestingly, the inconsistent proportion is much the same for people with a religion (27\%) and those without (25\%). The difference is that the former are mostly theists who do not expect there to be life after death, whereas the latter are split fairly evenly between God and life after death.

\section{A religious typology}

Rather than categorising people by whether they identify with a religion or not, or attend services or not, there would seem to be merit in using a more refined classification. The information on belief, and in particular the distinction between people who are sceptical about both God and life after death, those who believe in both, and the unorthodox (who believe in one but not the other), offers the opportunity to propose a new typology.

\section{Table 9. A religious typology}

\begin{tabular}{ccl} 
Type & $\%$ & Label \\
\hline 1 & 28 & Non-religious \\
2 & 7 & Nominally religious \\
3 & 21 & Unorthodox non-religious \\
4 & 5 & Unorthodox religious \\
& & \\
5 & 10 & Non-identifying believers \\
6 & 14 & Non-practising religious \\
7 & 15 & Actively religious
\end{tabular}

\section{Description}

Does not have a religion and believes in neither God nor life after death.

Identifies with a religion, but believes in neither God nor life after death.

Does not have a religion or does not attend services. Believes in God or life after death but not both.

Has a religion and attends services at least occasionally. Believes in God but not life after death (or in few cases, vice versa).

Does not have a religion, but believes in God and life after death.

Has a religion and believes in God and life after death. Does not attend services.

Has a religion and believes in God and life after death. Attends services. 
Seven religious types are described in Table 9. Note that attendance at services is only used to define categories 4, 6 and 7: the privately religious attend rarely or never, while the religious unorthodox and the actively religious do go at least sometimes. Although non-attendance is not a criterion for classification as non-religious, unreligious unorthodox, or private believers, practically all of the people in these groups are nonattenders (96\%, 97\% and 93\% respectively). Only nominals are somewhat mixed, and even here three quarters do not attend.

An alternative label for type 3 , the unorthodox non-religious, might be 'spiritual but not religious'. The 'spiritual' tag is less obviously appropriate than the 'not religious' one, however. These people express supernatural beliefs that do not seem to be conventionally Christian, but whether they have reflected on those beliefs is another matter. The lack of orthodoxy may suggest that the beliefs are weakly held, not that they reflect an unusual but carefully elaborated worldview.

The differences between men and women, and those with and without higher education, are most apparent among the non-religious and the actively religious (Table 10$)$. Nearly half $(47 \%)$ of men in the sample are non-religious or at best nominally religious, which is twice the proportion of women in those categories (24\%). There are no gender differences among the unorthodox. With education, what is most striking is the bimodal distribution of people with degrees. People with few or no qualifications are disproportionately likely to be unorthodox and nonreligious. To put it another way, the key dimensions of religious identity, belief and practice are typically consistent (whether present or absent) among the well educated and inconsistent for others. 
Table 10. Religious characteristics at age 42 by gender and education (\%)

Education

Variable
Raised according to any particular religion?
No

No

Christian, no denomination

Church of England/Anglican

Roman Catholic

Other Christian

Non-Christian

Men Women

Low Medium

High

Belongs to any particular religion?

No

$\begin{array}{rr}35 & 31 \\ 14 & 14 \\ 29 & 31 \\ 10 & 12 \\ 8 & 8 \\ 3 & 4\end{array}$

41

31

25

$12 \quad 16 \quad 15$

$28 \quad 31 \quad 31$

$10 \quad 10 \quad 13$

$6 \quad 8 \quad 11$

$3 \quad 3 \quad 5$

Christian, no denomination

$\begin{array}{rr}57 & 43 \\ 13 & 15 \\ 17 & 23 \\ 5 & 9 \\ 4 & 5 \\ 4 & 5\end{array}$

$\begin{array}{rrr}55 & 48 & 46 \\ 11 & 15 & 15 \\ 20 & 21 & 20 \\ 7 & 7 & 8 \\ 3 & 5 & 5 \\ 4 & 4 & 5\end{array}$

Attends any kind of religious service or meeting

Once a week or more

$\begin{array}{rrrrr}5 & 7 & 4 & 5 & 9 \\ 4 & 5 & 3 & 5 & 7 \\ 12 & 17 & 10 & 16 & 19 \\ 80 & 71 & 84 & 74 & 65\end{array}$

Once a month or more

Sometimes but less than once a month

Never or very rarely

Belief about God

I don't believe in God

I don't know whether there is a God

Higher Power, not personal God

I believe in God some of the time

While I have doubts, I believe in God

I know God really exists with no doubts

$\begin{array}{rr}30 & 15 \\ 24 & 19 \\ 14 & 14 \\ 9 & 14 \\ 15 & 23 \\ 9 & 15\end{array}$

$\begin{array}{rrr}23 & 19 & 25 \\ 23 & 21 & 19 \\ 13 & 14 & 15 \\ 12 & 13 & 9 \\ 18 & 20 & 19 \\ 11 & 12 & 14\end{array}$

Whether believes in life after death

Yes, definitely

$\begin{array}{rrrrr}12 & 25 & 19 & 19 & 17 \\ 23 & 36 & 32 & 32 & 24 \\ 39 & 31 & 34 & 35 & 36 \\ 26 & 9 & 15 & 15 & 23\end{array}$

No, probably not

26

15

23

Religious type

Non-religious

Nominally religious

$\begin{array}{rrrrr}38 & 19 & 28 & 25 & 32 \\ 9 & 5 & 7 & 7 & 8 \\ 21 & 21 & 24 & 21 & 16 \\ 5 & 6 & 3 & 6 & 7 \\ 8 & 12 & 12 & 10 & 6 \\ 9 & 18 & 16 & 16 & 10 \\ 11 & 19 & 10 & 16 & 21\end{array}$

Unorthodox non-religious

Unorthodox religious

Non-identifying believers

Non-practising religious

Actively religious

11

19

Notes. 'Medium' education includes GCSEs through diplomas; 'High' refers to degree-level qualifications. 


\section{Discussion / conclusion}

At first sight, birth cohort studies seem to offer an ideal opportunity to study the magnitude and direction of religious change over the life course. In the event, close examination of the multiple waves of the BCS70 mainly reveals an enormous amount of uncertainty in measurement, making it hard to detect whatever genuine change might have occurred.

The difficulty is foreshadowed by the responses at age 16 (the first sweep to collect any data on religion). On the one hand, $93 \%$ of cohort members said that they had been born into a religion. On the other hand, only $30 \%$ said that religion was either very important or quite important to them. The tension between having a religious heritage and not having much personal investment in religion colours all of their subsequent responses from young adulthood into middle age.

The first and most obvious result is a high degree of unreliability about reported past and present affiliation. Between 2004 and 2012, nearly a quarter (23\%) of people changed their answers about whether they had been raised in a religion. Between 1996 and 2012, more than a quarter (28\%) changed whether they saw themselves as belonging to a religion. Repeated cross-sectional surveys suggest that there is relatively little within-cohort change in religion and religiosity during adulthood, which implies that most of this movement results from the difficulty of pinning down something that respondents themselves are not very sure about.

The real changes that are most evident are those between age 16 and adulthood. Family influence will still be strong for many teenagers, and those reporting that religion was an important part of their lives were presumably describing family values. It is clear that a substantial proportion of those teenagers became relatively unreligious adults: of individuals who said at age 16 that religion was either very or quite important in their lives, barely more than a third (35\%) described themselves as practising at age 34 and half said at age 42 that they never attend services. There is some movement in the opposite direction, but not nearly enough to compensate for the losses to religion.

The addition of questions on religious belief in 2012 allows us to classify the respondents by religiosity with a great deal more confidence than previously. The complexity of this topic is immediately apparent; some people seem wholly non-religious and a smaller number are actively (and consistently) religious, but the majority fall into intermediate categories that are defined by nominal allegiance, unorthodox belief, or belief in the absence of affiliation or practice (Voas, 2009). There are differences between men and women on all of the measures studied here, but the gender gaps are particularly striking for belief. The question of why women appear to be so much more religious than men, despite the trends towards both gender equality and secularity, is a large issue that has received a great deal of attention without producing any clear resolution (Trzebiatowska \& Bruce, 2012; Voas, McAndrew, \& Storm 2013).

If there is a moral, it may be that while single item measures may be useful for looking at religious trends if consistently worded, they are not especially helpful at the individual level. We need multiple items across all three key domains (identity, practice and belief) to obtain a reliable picture of religious commitment. With longitudinal studies, the questions should ideally be introduced at an early stage in order to study religious change over the life course.

\section{Acknowledgements}

The author receives funding from the UK Economic and Social Research Council via the ESRC Research Centre on Micro-Social Change. Two anonymous referees provided valuable comments on an earlier version. The author is grateful to Alice Sullivan and Matt Brown, who collaborated on an earlier BCS70 data note that helped to motivate this study. 


\section{References}

Astley, J. (2010). SCM Studyguide: Christian doctrine. London: SMC Press.

Beckford, J.A., \& Demerath, N.J. (Eds.). (2007). The Sage handbook of the sociology of religion. London: Sage.

Bengtson, V.L. (2013). Families and faith: How religion is passed down across generations. New York: Oxford University Press. http://dx.doi.org/10.1093/acprof:oso/9780199948659.001.0001

Bruce, S. (2011). Secularization: In defence of an unfashionable theory. Oxford: Oxford University Press.

Clarke, P. (2009). The Oxford handbook of the sociology of religion. New York: Oxford University Press.

Crockett, A., \& Voas, D. (2006). Generations of decline: Religious change in twentieth-century Britain. Journal for the Scientific Study of Religion, 45(4), 567-584. http://dx.doi.org/10.1111/j.14685906.2006.00328.x

Dillon, M., \& Wink, P. (2007). In the course of a lifetime: Tracing religious beliefs, practice, and change. Berkeley: University of California Press. http://dx.doi.org/10.1525/california/9780520249004.001.0001

Fenn, R.K. (2000). The Blackwell companion to the sociology of religion. Oxford: Wiley-Blackwell.

Hadaway, C. K, Marler, P.L., \& Chaves, M. (1993). What the polls don't show: A closer look at U.S. church attendance. American Sociological Review, 58(6), 741-752. http://dx.doi.org/10.2307/2095948

Heelas, P., \& Woodhead, L. (2005). The spiritual revolution: Why religion is giving way to spirituality. Oxford: Blackwell.

Koenig, H., King, D., \& Carson, V.B. (2012). Handbook of religion and health, second edn. New York: Oxford University Press.

Lim, C., MacGregor, C.A., \& Putnam, R.D. (2010). Secular and liminal: Discovering heterogeneity among religious nones. Journal for the Scientific Study of Religion, 49(4), 596-618. http://dx.doi.org/10.1111/j.1468-5906.2010.01533.x

Ni Bhrolchain, M., Beaujouan, É., \& Murphy, M.J. (2011). Sources of error in reported childlessness in a continuous British household survey. Population Studies, 65(3), 305-318. http://dx.doi.org/10.1080/00324728.2011.607901

Stark, R., \& Finke, R. (2000). Acts of faith: Explaining the human side of religion. Berkeley, CA: University of California Press.

Stolzenberg, R.M., Blair-Loy, M., \& Waite, L.J. (1995). Religious participation in early adulthood: Age and family life cycle effects on church membership. American Sociological Review, 60(1), 84-103. http://dx.doi.org/10.2307/2096347

Sullivan, A., Voas, D., \& Brown, M. (2012). BCS70 data note: The art of asking questions about religion. Centre for Longitudinal Studies, Institute of Education.

Trzebiatowska, M., \& Bruce, S. (2012). Why are women more religious than men? Oxford: Oxford University Press. http://dx.doi.org/10.1093/acprof:oso/9780199608102.001.0001

Turner, B.S. (2010). The new Blackwell companion to the sociology of religion.

Oxford: Wiley-Blackwell. http://dx.doi.org/10.1002/9781444320787

Voas, D. (2003). Intermarriage and the demography of secularisation. British Journal of Sociology, 54(1), 83108. http://dx.doi.org/10.1080/0007131032000045914

Voas, D. (2007a). Does religion belong in population studies? Environment \& Planning A, 39(5), 1166-1180. http://dx.doi.org/10.1080/0007131032000045914

Voas, D. (2007b). Surveys of behaviour, beliefs and affiliation. In J. Beckford \& N.J. Demerath (Eds.), The Sage handbook of the sociology of religion (pp. 128-150). London: Sage. http://dx.doi.org/10.4135/9781848607965.n8

Voas, D. (2009). The rise and fall of fuzzy fidelity in Europe. European Sociological Review, 25(2), $155-168$. http://dx.doi.org/10.1093/esr/jen044

Voas, D., \& Bruce, S. (2004). The 2001 census and Christian identification in Britain. Journal of Contemporary Religion, 19(1), 23-28. http://dx.doi.org/10.1080/1353790032000165087

Voas, D., \& Crockett, A. (2005). Religion in Britain: Neither believing nor belonging. Sociology, 39(1), $11-28$. http://dx.doi.org/10.1177/0038038505048998

Voas, D., McAndrew, S., \& Storm, I. (2013). Modernization and the gender gap in religiosity: Evidence from cross-national European surveys. Kölner Zeitschrift für Soziologie und Sozialpsychologie, 65, 259-283. http://dx.doi.org/10.1007/s11577-013-0226-5 